\title{
PERBEDAAN HUKUM PEMBUKTIAN DALAM PERSPEKTIF HUKUM ACARA PIDANA DAN PERDATA
}

\author{
Oleh Hendri Jayadi Pandiangan ${ }^{1}$ \\ Email: hendrijayadi79@gmail.com \\ Universitas Kristen Indonesia
}

\begin{abstract}
Proof is the act of proving that in general it has the same purpose, namely to provide certainty about the truth of an event. The act of proving in a trial is indeed used the notion of juridical proof, that is, proof in the court is not possible for logical and absolute proof, therefore in examining the evidence in the trial it is known as things that are close to the truth. But actually if it is analyzed more deeply in certain matters it can also happen that the evidence in the trial is logical and absolute. Proof in the practical order is a very important thing to test the truth or legal facts that actually occur. The Defendant's fate in the trial at the Court was very much determined by the evidence that could be used as the basis for the judge in making a verdict against him. In such civil procedure, the fate of the parties, both the Plaintiff and the Defendant, is very much determined by the presentation of the evidence by the parties. The evidentiary difference in criminal procedure law and civil procedural law is that in the criminal proof the proof of system is "negatief wettelijk stelsel", the system of verification according to the law negatively is a theory of a combination of a positive legal proof system with conviction-in time. Whereas the characteristic of civil proof is "audi et alterem partem", the party who postulates that it must prove the argument.
\end{abstract}

\section{Keywords: hukum pembuktian, hukum acara pidana, hukum acara perdata}

\section{Pendahuluan}

Pembuktian dalam tatanan praktis adalah hal yang sangat penting untuk menguji kebenaran atau fakta hukum yang sebenar-benarnya terjadi. Nasib seorang Terdakwa dalam persidangan di Pengadilan sangat ditentukan oleh bukti-bukti yang dapat dijadikan dasar bagi hakim dalam menjatuhkan vonis terhadap dirinya. Dalam hukum acara perdatapun demikian "nasib" para pihak baik Penggugat maupun Tergugat sangat ditentukan oleh penyajian bukti-bukti oleh para pihak. Banyak terjadi seorang Terdakwa yang sebenarnya tidak terbukti melakukan tindak pidana yang didakwakan, mendapat vonis dan dinyatakan bersalah oleh Majelis Hakim yang memeriksa dan mengadili perkaranya. Hal mana kerap kali terjadi karena Terdakwa dan atau Penasehat Hukum nya tidak piawai dalam memahami bagaimana menyajikan bukti-bukti dalam persidangan. Ketidakfahaman ini sangat berbahaya bagi nasib Terdakwa. Demikianpun dalam persidangan perdata, kerapkali terjadi putusan hakim dikeluarkan dengan tidak mempertimbangkan bukti-bukti yang diajukan oleh para pihak baik Penggugat maupun Tergugat. Semua ini terjadi karena

${ }^{1}$ Dosen Tetap Fakultas Hukum Universitas Kristen Indonesia. belum adanya pemahaman yang mumpuni tentang pembuktian dalam hukum acara di Indonesia.

Pemahaman terhadap pembuktian harus dimiliki oleh para ahli hukum dan penegak hukum yang lazimnya disebut "catur wangsa penegak hukum" yakni Polisi, Jaksa, Hakim dan Advokat. Tidak ada lagi pemaksaan kehendak terhadap jalannya suatu perkara baik pidana maupun perdata. Jika tidak memiliki bukti yang kuat maka penegak hukum harus berani menyatakan perkara dihentikan dalam penyidikan oleh Kepolisian Republik Indonesia atau penuntutan dihentikan dalam penuntutan oleh Jaksa dalam kedudukannya sebagai Penuntut Umum. Demikian halnya dalam pemeriksaan dipersidangan Majelis Hakim harus benar-benar memeriksa perkara berdasarkan bukti-bukti yang terungkap dalam persidangan. Jika tidak terbukti maka harus berani membebaskan Terdakwa(vrijspraak) ataumenyatakan Terdakwa lepas dari tuntutan hukum (onslag van rechtsvervolging) demikian pun sebaliknya. Bagi Advokat pun hal ini sangat penting, karena nasib Klien ada ditangan advokat ketika bersidang di persidangan. Advokat harus piawai dalam menyajikan bukti-bukti guna meyakinkan Majelis Hakim dalam mengeluarkan putusannya kelak. 


\section{Permasalahan}

Bagaimana membedakan pembuktian dalam Hukum Acara Pidana dan Hukum Acara Perdata?

\section{Tujuan Penulisan}

Untuk mengetahui perbedaan pembuktian dan persamaan dalam Hukum Acara Pidana dan Hukum Acara Perdata.

\section{Pengertian Pembuktian pada Umumnya}

Apakah yang dimaksud dengan membuktikan? Membuktikan mengandung beberapa pengertian: ${ }^{2}$

1. Kata membuktikan dikenal dalam arti logis. Membuktikan di sini berarti memberi kepastian yang bersifat mutlak, karena berlaku bagi setiap orang yang tidak memungkinkan adanya bukti lawan. Berdasarkan suatu axioma, yaitu asasasas umum yang kenal dalam ilmu pengetahuan, dimungkinkan adanya pembuktian yang bersifat mutlak yang tidak memungkinkan adanya bukti lawan. Berdasarkan suatu axioma bahwa dua garis yang sejajar tidak mungkin bersilang dapat dibuktikan bahwa dua kaki dari sebuah segitiga tidak mungkin sejajar. Terhadap pembuktian ini tidak dimungkinkan adanya bukti lawan, kecuali itu pembuktian itu berlaku bagi setiap orang. Disini axioma dihubungkan menurut ketentuanketentuan logika dengan pengamatanpengamatan yang diperoleh dari pengalaman, sehingga diperoleh kesimpulan-kesimpulan yang memberi kepastian yang bersifat mutlak;

2. Kata membuktikan dikenal juga dalam arti konvensionil. Disini pun membuktikan berarti juga memberi kepastian, hanya saja bukan kepastian mutlak, melainkan kepastian yang nisbi atau relatif sifatnya yang mempunyai tingkatantingkatan:

a. Kepastian yang didasarkan atas perasaan belaka. Karena didasarkan atas perasaan maka kepastian ini bersifat intuitif dan disebut conviction in time;

b. Kepastian yang didasarkan atas pertimbangan akal, maka oleh karena itu disebut conviction raisonnee.

3. Membuktikan dalam hukum acara mempunyai arti yuridis. Di dalam ilmu hukum tidak dimungkinkan adanya pembuktian yang logis dan mutlak yang berlaku bagi setiap orang serta menutup segala kemungkinan akan bukti lawan, akan tetapi

\footnotetext{
${ }^{2}$ Sudikno Mertokusumo, Hukum Acara Perdata Indonesia, Liberty, Yogyakarta, 1988, hlm. 103.
}

merupakan pembuktian yang konvensionil yang bersifat khusus. Pembuktian dalam arti yuridis ini hanya berlaku bagi pihak-pihak yang berperkara atau yang memperoleh hak dari mereka. Dengan demikian pembuktian dalam arti yuridis tidak menuju kepada kebenaran mutlak. Ada kemungkinannya bahwa pengakuan, kesaksian atau surat-surat itu tidak benar atau palsu atau dipalsukan. Maka dalam hal ini dimungkinkan adanya bukti lawan. Pembuktian secara yuridis tidak lain merupakan pembuktian historis. Pembuktian yang bersifat historis ini mencoba menetapkan apa yang telah terjadi secara konkret, baik dalam pembuktian yang yuridis maupun yang ilmiah, maka membuktikan pada hakekatnya berarti mempertimbangkan secara logis mengapa peristiwa-peristiwa tertentu dianggap benar. Dalam pembuktian secara yuridis, sering terjadi bahwa pengamatannya sebagai dasar daripada pembuktian tidak bersifat langsung didasarkan atas penglihatan, tetapi didasarkan atas kesaksian oleh orang lain. Kecuali itu dipisahkan antara pihak yang mengajukan alat-alat bukti dan pihak yang harus menetapkan bahwa sesuatu telah terbukti. Membuktikan dalam arti yuridis tidak lain berarti memberi dasar-dasar yang cukup kepada hakim yang memeriksa perkara yang bersangkutan guna memberi kepastian tentang kebenaran peristiwa yang diajukan.

Berdasarkan pendapat ahli di atas maka tindakan membuktikansecaraumummemilikitujuanyangsama yaitu guna memberikan kepastian tentang kebenaran suatu peristiwa. Tindakan membuktikan dalam suatu persidangan memang digunakan pengertian pembuktian secara yuridis yaitu pembuktian di persidangan tidak dimungkinkan adanya pembuktian yang logis dan mutlak, oleh karenanya dalam pemeriksaan bukti-bukti dipersidangan dikenal dengan istilah hal-hal yang mendekati kebenaran. Akan tetapi sebenarnya jika dianalisa lebih dalam lagi dalam hal-hal tertentu dapat juga terjadi pembuktian dipersidangan itu bersifat logis dan mutlak, hal ini dapat terjadi berdasarkan faktor-faktor sebagai berikut:

1. Bukti-bukti tentang terjadinya suatu peristiwa tidak dibantah kebenarannya oleh pihak lawan. Oleh karenanya hakim sebagai pemutus perkara tidak perlu untuk membuktikan kebenarannya. Kebiasaan ini dapat terlihat dalam setiap surat jawaban perkara yang diberikan oleh pihak tergugat dalam persidangan perdata, sebagai tanggapan dari surat gugatan dan seakan-akan menjadi bahasa baku yakni kalimat "tergugat menolak seluruh dalil-dalil yang diajukan oleh 
penggugat kecuali terhadap hal-hal yang diakui kebenarannya secara tegas oleh tergugat";

2. Bukti-bukti yang diperoleh dari hasil rekonstruksi. Proses rekonstruksi biasanya peristiwa-peristiwa yang direka ulang berdasarkan pengakuan dari si pelaku untuk membuat terang adanya suatu peristiwa hukum. Sehingga apabila dalam suatu persidangan itu diperoleh bukti-bukti dan buktibukti itu direkonstruksi untuk menggambarkan suatu peristiwa hukum maka secara logis akan sulit membantah kebenaran dari peristiwa tersebut.

Dalam persidangan baik perdata maupun pidana hukum acara menjadi dasar dan aturan main dalam proses pembuktian yang ada, maka peran hakim dalam menilai suatu bukti harus benar-benar cermat dan teliti. Dalam persidangan hakekat pembuktian berarti memberi kepastian kepada hakim tentang adanya peristiwaperistiwa tertentu. Secara tidak langsung hakim yang harus menguraikan peristiwa, mengkwalifisirnya, kemudian menganalisa dasar hukumnya, sehingga tujuan pembuktian untuk membuktikan kebenaran adanya peristiwa hukum adalah putusan hakim yang didasarkan atas pembuktian tersebut. Walaupun putusan itu diharuskan obyektif, namun dalam hal pembuktian dibedakan antara pembuktian dalam perkara pidana yang mensyaratkan adanya keyakinan dan pembuktian dalam perkara perdata yang tidak secara tegas mensyaratkan adanya keyakinan.

\section{Teori-Teori Sistem Pembuktian}

Sebagaimana telah dijelaskan sebelumnya bahwa pembuktian bertujuan untuk mengetahui bagaimana cara meletakan hasil pembuktian terhadap perkara yang sedang diperiksa. Hasil dan kekuatan pembuktian yang bagaimana dapat dianggap cukup memadai membuktikan kesalahan terdakwa, apakah dengan terpenuhi pembuktian minimum sudah dapat dianggap cukup membuktikan kesalahan terdakwa? apakah dengan lengkapnya pembuktian dengan alatalat bukti, masih diperlukan faktor atau unsur keyakinan hakim? pertanyaan-pertanyaan inilah yang akan dijawab oleh sistem pembuktian dalam hukum acara pidana. Sebelum menguraikan sistem pembuktian dalam persidangan pengadilan, ada baiknya ditinjau beberapa ajaran yang berhubungan dengan sistem pembuktian, gunanya sebagai perbandingan dalam memahami sistem pembuktian berdasarkan hukum acara yang berlaku baik secara perdata maupun pidana.

Berkaitan dalam menilai pembuktian hakim dapat bertindak bebas atau diikat oleh undang-undang, maka timbulah pertanyaan sampai berapa jauhkah hukum positif boleh mengikat hakim atau para pihak dalam pembuktian peristiwa didalam sidang? tentang hal ini ada tiga teori ${ }^{3}$ :

1. Teori pembuktian bebas. Teori ini tidak menghendaki adanya ketentuan-ketentuan yang mengikat hakim, sehingga penilaian pembuktian diserahkan kepada hakim yang memutus perkara.

2. Teori pembuktian negatif. Menurut teori ini harus ada ketentuan-ketentuan yang mengikat, yang bersifat negatif yaitu ketentuan ini harus membatasi pada larangan kepada hakim untuk melakukan sesuatu yang berhubungan dengan pembuktian dengan pengecualian, misalnya dalam Pasal 169 HIR yang berbunyi: "Keterangan dari seorang saksi saja, dengan tidak ada sesuatu alat bukti yang lain, tiada dapat dipercaya di dalam hukum". Pasal 1905 Kitab Undang-Undang Hukum Perdata yang berbunyi: "Keterangan seorang saksi saja, tanpa suatu alat bukti lain, dimuka pengadilan tidak boleh dipercaya"

3. Teori pembuktian pasif. Menurut teori ini pembuktian menghendaki adanya perintah kepada hakim untuk membuktikan fakta-fakta hukum. Dalam teori ini hakim diwajibkan untuk membuktikan akan tetapi tindakannya dibatasi dengan dengan syarat-syarat, misalnya Pasal 165 HIR yang berbunyi:

"Akta otentik, yaitu suatu surat yang diperbuat oleh atau dihadapan pegawai umum yang berkuasa akan membuatnya, mewujudkan bukti yang cukup bagi kedua belah pihak dan ahli warisnya serta sekalian orang yang mendapat hak dari padanya, yaitu tentang segala hal, yang tersebut di dalam surat itu dan juga tentang yang tercantum dalam surat itu sebagai pemberitahuan sahaja; tetapi yang tersebut kemudian ituhanya sekedar yang diberitahuka itu langsung berhubung dengan pokok dalam akta itu"

Dalam ilmu pengetahuan terdapat beberapa teori tentang beban pembuktian yang dapat merupakan pedoman bagi hakim dalam memeriksa dan memutus perkara ${ }^{4}$,yaitu:

\section{Sistem Pembuktian Berdasarkan Keyakinan Hakim (conviction-in time)}

Sistem pembuktian coviction-in time menentukan salah tidaknya seorang terdakwa, semata-mata ditentukan oleh penilaian keyakinan hakim.

\footnotetext{
${ }^{3}$ Ibid, hlm. 109.

${ }^{4}$ M. Yahya Harahap, 2001, Pembahasan Permasalahan dan Penerapan KUHAP (Pemeriksaan Sidang Pengadilan, Banding, Kasasi, dan Peninjauan Kembali) Edisi Kedua, Sinar Grafika, Jakarta, hlm. 227.
} 
Keyakinan hakim yang menentukan keterbuktian kesalahaan terdakwa. Dari mana hakim menarik dan menyimpulkan keyakinannya, tidak menjadi masalah dalam sistem ini. Keyakinannya boleh diambil dan disimpulkan hakim dari alat-alat bukti yang diperiksanya dalam sidang pengadilan. Bisa juga hasil pemeriksaan alat-alat bukti itu diabaikan hakim dan langsung menarik keyakinan dari keterangan atau pengakuan terdakwa. Sistem pembuktian convictionin time memiliki kelemahaan.

Hakim dapat saja menjatuhkan hukuman pada seorang terdakwa semata-mata atas dasar keyakinan semata tanpa didukung oleh alat bukti yang cukup. Sebaliknya hakim leluasa membebaskan terdakwa dari tindak pidana yang dilakukan walaupun kesalahan terdakwa telah cukup terbukti dengan alatalat bukti yang lengkap, selama hakim tidak yakin atas kesalahan terdakwa. Sehingga dapat disimpulkan sistem pembuktian conviction-in time, sekalipun kesalahan terdakwa sudah cukup terbukti, pembuktian yang cukup itu dapat dikesampingkan keyakinan hakim. Sebaliknya sekalipun kesalahan terdakwa tidak terbukti berdasar alat-alat bukti yang sah, terdakwa dinyatakan bersalah, semata-mata atas dasar keyakinan hakim.

Keyakinan hakim yang dominan atau yang paling menentukan salah atau tidaknya terdakwa. Dalam teori conviction-in time keyakinan hakim tanpa alat bukti yang sah sudah cukup membuktikan kesalahan terdakwa. Dalam teori ini seolah-olah nasib terdakwa diserahkan sepenuhnya kepada keyakinan hakim semata-mata. Keyakinan hakimlah yang menentukan wujud kebenaran sejati dalam sitem pembuktian ini.

\section{Sistem Pembuktian Berdasarkan Keyakinan Hakim Atas Alasan yang Logis (conviction- raissonee)}

Dalam sistem ini pun dapat dikatakan keyakinan hakim tetap memegang peranan penting dalam menentukan salah tidaknya terdakwa. akan tetapi, dalam sistem pembutian ini, faktor keyakinan hakim dibatasi. Jika dalam sistem pembuktian conviction- in time peran keyakinan hakim leluasa tanpa batas, maka pada sistem conviction-raissonee, keyakinan hakim harus didukung dengan alasan-alsan yang jelas. Hakim menguraikan dan menjelaskan alasanalasan apa yang mendasari keyakinannya harus dilandasi reasoning atau alasan-alasan dan reasoning itu harus reasonable, yakni berdasar alasan yang dapat diterima. Keyakinan hakim hanya mempunyai dasar-dasar alasan yang logis dan benar-benar dapat diterima akal, tidak semata-mata atau dasar keyakinan yang tertutup tanpa uraian alasan yang masuk akal.

\section{Pembukian Menurut Undang-Undang Secara Positif}

Pembuktian menurut undang-undang secara positif merupakan pembuktian yang bertolak belakang dengan sistem pembuktian menurut keyakinan hakim atau conviction-in time.

Dalam pembuktian menurut undang-undang secara positif, keyakinan hakim tidak ikut ambil bagian dalam membuktikan kesalahan terdakwa, keyakinan hakim dalam sistem ini, tidak ikut berperan menentukan salah atau tidaknya terdakwa. Sistem ini berpedoman pada prinsip pembuktian dengan alat-alat yang ditentukan undang-undang. Untuk membuktikan salah atau tidaknya terdakwa digantungkan kepada alat-alat bukti yang sah. Asal sudah dipenuhi syarat- syarat dan ketentuan pembuktian menurut undang- undang, sudah cukup menentukan kesalahan terdakwa tanpa mempersoalkan keyakinan hakim. Apakah hakim yakin atau tidak tentang kesalahan terdakwa, bukan menjadi masalah. Pokoknya, apabila sudah terpenuhi cara-cara pembuktian dengan alat-alat bukti yang sah menurut undang-undang. Hati nuraninya tidak tidak ikut hadir dalam menentukan salah atau tidaknya terdakwa. meskipun demikian, dari satu sisi sistem ini mempunyai kebaikan. Sistem ini benar-benar menuntut hakim wajib mencari dan menemukan kebenaran salah atau tidaknya terdakwa sesuai dengan tata cara pembuktian dengan alat-alat yang telah ditentukan undang-undang.

Dari sejak pemeriksaan perkara dimulai, hakim harus melemparkan dan mengesampingkan jauhjauh faktor keyakinan, tetapi semata-mata berdiri tegak pada nilai pembuktian yang objektif tanpa mencampuraduk hasil pembuktian yang diperoleh dipersidangan dengan unsur subjektif keyakinannya. Sekali majelis hakim menemukan hasil pembuktian yang objektif seuai dengan cara-cara dan alat-alat bukti yang sah menurut undang-undang, tidak perlu lagi menanyakan dan menguji hasil pembuktian tersebut dengan keyakinan hati nuraninya.

Sistem pembutian menurut undang-undang secara positif lebih sesuai dibandingkan dengan sistem menurut keyakinan. Sistem menurut undangundang secara positif, lebih dekat kepada perinsip penghukuman berdasar hukum artinya penjatuhan hukuman terhadap terdakwa semata-mata tidak diletakan dibawah kewenangan hakim, tetapi diatas kewenangan undang-undang yang berlandasan asas seorang terdakwa baru dapat dihukum dan dipidana jika apa yang didakwakan kepadanya benar-benar terbukti berdasar cara dan alat-alat bukti yang sah menurut undang-undang. 


\section{Pembuktian Menurut Undang-Undang Secara negatif (negatief wettelijk stelsel)}

Sistem pembuktian menurut undang-undang secara negatif merupakan teori gabungan antara sitem pembuktian menurut undang-undang secara positif dengan sistem pembuktian menurut keyakinan atau conviction- in time.

Sistem pembuktian menurut undang-undang secara negatif merupakan keseimbangan antara kedua sistem yang bertolak belakang secara ekstrem. Dari keseimbangan tersebut, sistem pembuktian menurut undang-undang secara negatif menggabungkan kedalam dirinya secara terpadu sitem pembuktian menurut keyakinan dengan sistem pembuktian menurut undang-uandang secara positif. Dari hasil penggabungan kedua sistem yang saling bertolak belakang itu, terwujdlah suatu sistem pembuktian menurut undang-undang secara negatif. Rumusannya berbunyi, salah tidaknya seseorang ditentukan oleh keyakinan hakim yang didasarkan kepada cara dan dan dengan alat-alat bukti yang sah menurutundangundang.

Berdasarkan rumusan di atas untuk menyatakan salah atau tidaknya seorang terdakwa tidak cukup berdasarkan keyakinan hakim semata-mata. Atau hanya semata-mata didasarkan pada ketentuan dan cara pembuktian dengan alat-alat bukti yang ditentukan undang-undang. Seorang terdakwa baru dinyatakan bersalah apabila kesalahan yang didakwakan kepadanya dapat dibuktikan dengan cara dan dengan alat-alat bukti yang sah menurutundangundang serta sekaligus keterbuktian kesalahan itu dibarengi dengan keyakinan hakim. Bertitik tolak dari uraian pembuktian undang-undang secara negatif, terdapat dua komponen, yakni (a) pembuktian harus dilakukan menurut cara dan dengan alat-alat bukti yang sah menurut udang-undang, dan (b) keyakinan hakim juga harus didasarkan atas cara dan dengan alat-alat bukti yang sah menurut undang-undang.

Dengan demikian sistem ini memadukan unsur objektif dan subjektif dalam menentukan salah atau tidaknya terdakwa. Tidak ada yang paling dominan diantara kedua unsur tersebut. Jika salah satu di antara dua unsur itu tidak ada, tidak cukup mendukung keterbuktian kesalahan terdakwa, misalnya ditinjau dari segi cara dan dengan alat-alat bukti yang sah menurut undang-undang kesalahan terdakwa cukup terbukti, tetapi sekali sudah cukup terbukti, hakim tidak yakin akan kesalahan terdakwa dalam hal seperti ini terdakwa tidak dapat dinyatakan besalah. Sebaliknya, hakim benar-benar yakin terdakwa sungguh-sungguh bersalah melakukan kejahatan yang didakwakan. Akan tetapi, keyakinan tersebut tidak didukung dengan pembuktian yang cukup menurut cara dan dengan alat-alat bukti yang sah menurut undang-undang. Dalam hal seperti ini terdakwa tidak dapat dinyatakan bersalah. Oleh karena itu, di antara kedua komponen tersebut harus saling mendukung.

Pembuktian menurut undang-undang secara negatif menempatkan keyakinan hakim yang paling berperan dan dominan dalam menentukan salah atau tidaknya terdakwa. Walaupun kesalahan terdakwa telah cukup terbukti menurut cara dan dengan alat bukti yang sah pembuktian itu dapat ditiadakan atau tidak dipertimbangkan oleh keyakinan hakim, apalagi pada diri hakim terdapat motivasi yang tidak terpuji demi keuntungan pribadi dengan suatu imbalan materi dapat dengan mudah membebaskan terdakwa dari pertanggung jawaban hukum atas alasan hakim tidak yakin akan kesalahan terdakwa. Misalnya cukup terbukti secara sah namun sekalipun terbukti secara sah tetapi hakim tidak yakin akan kesalahan yang telah terbukti tersebut, oleh karena itu terdakwa harus dibebaskan dari tuntutan hukum. Disinilah letak kelemahan sistem ini, akan tetapi dalam praktek, secara terselubung unsur keyakinan hakim yang paling menentukan dan dapat melemparkan secara halus pembuktian yang cukup. Terutama bagi seorang hakim yang kurang hati-hati, gampang sekali memanfaatkan sistem pembuktian ini dengan suatu imbalan yang diberikan oleh terdakwa. Akan tetapi, kita sadar di manakah dijumpai didunia ini suatu sisten yang sempurna tanpa cacat? Bagaimana pun baik buruknya suatu sistem, semuanya sangat tergantung kepada manusia yang berada di belakang sistem yang bersangkutan.

\section{Hukum Pembuktian dalam Perspektif Hukum Acara Pidana}

Penegakkan hukum acara pidana khususnya di Indonesia pada prinsipnya adalah mencari kebenaran materil. Untuk dapat mengungkap sebuah kebenaran materil maka sangat diperlukan suatu tindakan pembuktian. Oleh karenanya pembuktian memiliki fungsi yang sangat penting dan merupakan titik sentral dalam proses pemeriksaan perkara pidana.

Arti pembuktian ditinjau dari segi hukum acara pidana, ${ }^{5}$ antara lain:

1. Ketentuan yang membatasi sidang pengadilan dalam usaha mencari dan mempertahankan kebenaran. Baik hakim, penuntut umum, terdakwa, atau penasihat hukum, semua terikat padaketentuan tata cara dan penilaian alat bukti yang ditentukan

\footnotetext{
${ }^{5}$ M. Yahya Harahap, op cit, hlm 274
} 
undang-undang. Tidak boleh leluasa bertindak dengan caranya sendiri dalam menilai pembuktian. Dalam mempergunakan alat bukti, tidak boleh bertentangan dengan undang-undang. Terdakwa tidak bisa leluasa mempertahankan sesuatu yang dianggapnya diluar ketentuan yang telah digariskan undang-undang.

Terutama bagi majelis hakim, harus benar-benar sadar dan cermat menilai dan mempertimbangkan kekuatan pembuktian yang ditemukan dalam kebutuhan yang akan dijatuhkan, kebenaran itu harus diuji dengan alat bukti, dengan cara dan dengan kekuatan pembuktian yang melekat pada setiap alat bukti yang ditemukan. Kalau tidak demikian bisa saja orang yang jahat lepas dan orang yang tak bersalah mendapat ganjaran hukuman.

2. Sehubungan dengan pengertian di atas, majelis hakim dalam mencari dan meletakan kebenaran yang akan dijatuhkan dalam putusan, harus berdasarkan alat-alat bukti yang telah ditentukan undang-undang secara limitatif, sebagaimana yang disebut dalam pasal 184 KUHAP.

Berdasarkan arti pembuktian sebagamana diuraiakan di atas maka dapat disimpulkan bahwa pembuktian adalah suatu tindakan atau upaya untuk membuktian kesalahan yang didakwakan kepada terdakwa. Dengan kata lain pembuktian juga berfungsi untuk menyatakan kebenaran dari sebuah tuduhan atau dakwaan. Pembuktian juga merupakan ketentuan yang mengatur alat-alat bukti yang dibenarkan oleh undang-undang yang boleh dipergunakan hakim untuk membuktikan kesalahan yang didakwakan.

KUHAP memiliki sifat pembuktian yang limitatif, artinya mengenai hal-hal yang dibuktikan hanya terbatas pada hal-hal yang diatur dalam KUHAP itu sendiri. Begitu pula dalam cara mempergunakan dan menilai kekuatan pembuktian yang melekat pada setiap alat bukti, hanya boleh dilakukan dalam batasbatas yang dibenarkan oleh undang-undang. Hal tersebut dilakukan agar dalam mewujudkan kebenaran yang hendak dijatuhkan, majelis hakim terhindar dari pengorbanan kebenaran yang harus dibenarkan. Jangan sampai kebenaran yang diwujudkan dalam putusan merupakan hasil perolehan yang keluar dari garis yang dibenarkan dalam sistem pembuktian, sehingga dalam putusannya tidak berdasarkan oleh perasaan dan pendapat subjektif hakim.

Pasal 183 KUHAP, yang berbunyi: "Hakim tidak boleh menjatuhkan pidana kepada seseorang kecuali apabila dengan sekurang-kurangnya dua alat bukti yang sah ia memperoleh keyakinan bahwa suatu tindak pidana benar-benar terjadi dan bahwa terdakwalah yang bersalah melakukannya."

Jika dibandingkan bunyi Pasal 183 KUHAP dengan Pasal 294 HIR, hampir sama bunyi dan maksud yang terkandung didalamnya.

Pasal 294 HIR, yang berbunyi: "Tidak akan dijatuhkan hukuman kepada seseorang pun jika hakim tidak yakin kesalahan terdakwa dengan upaya bukti menurut undang-undang bahwa benar telah terjadi perbuatan pidana dan bahwa tertuduhlah yang salah melakukan perbuatan itu".

Dari bunyi pasal tersebut, baik yang termuat pada pasal 183 KUHAP maupun yang dirumuskan dalam Pasal 294 HIR, sama-sama menganut sistem pembuktian menurut undang-undang secara negatif. Perbedaan antara keduanya, hanya terletak pada penekanan saja. Pada Pasal 183 KUHAP, syarat pembuktian menurut cara dan alat bukti yang sah, lebih ditekankan dalam perumusannya. Hal ini dapat dibaca dalam kalimat: ketentuan pembuktian yang memadai untuk menjatuhkan pidana kepada seseorang terdakwa sekurang-kurangnya dua alat bukti yang sah. Dengan demikian Pasal 183 KUHAP mengatur, untuk menentukan salah satu tidaknya seseorang terdakwa dan untuk menjatuhkan pidana kepada terdakwa, harus:

1. Kesalahannya terbukti dengan sekurangkurangnya dua alat bukti yang sah dan;

2. Keterbuktiannya dengan sekurang-kurangnya dua alat bukti yang sah, hakim memperoleh keyakinan bahwa tindak pidana benar-benar terjadi dan bahwa terdakwalah yang bersalah melakukannya.

Untuk menjajaki alasan pembuat undang-undang merumuskan Pasal 183 KUHAP, barangkali ditunjukan untuk mewujudkan suatu ketentuan yang seminimal mungkin dapat menjamin tegaknya kebenaran sejati serta tegaknya keadilan dan kepastian hukum pendapat ini dapat diambil dari makna penjelasan Pasal 183. Dari penjelasan Pasal 183 pembuat undang-undang telah menentukan pilihan bahwa sistem pembuktian yang paling tepat dalam kehidupan penegakan hukum di Indonesia ialah sistem pembuktian menurut undangundang secara negatif, demi tegaknya keadilan, kebenaran, dan kepastian hukum. Dalam sistem pembuktian ini, terpadu kesatuan penggabungan antara sistem conviction in time dengan sistem pembuktian menurut undang-undang secara positif (positief wettelijk stelsel).

KUHAP telah mengatur beberapa pedoman mengenai pembuktian ${ }^{6}$, yaitu:

${ }^{6}$ Ibid, hlm. 274. 
1. Penuntut umum bertindak sebagai aparat yang diberi wewenang untuk mengajukan segala apa daya upaya membuktikan kesalahan yang didakwakan kepada terdakwa;

2. Sebaliknya terdakwa atau penasehat hukum mempunyai hak untuk melumpuhkan pembuktian yang diajukan penuntut umum, sesuai dengan cara-cara dibenarkan undang-undang, berupa "sangkalan" atau bantahan yang beralasan dengan yang meringankan atau saksi a decharge maupun dengan "alibi";

3. Pembuktian juga bisa berarti suatu penegasan bahwa ketentuan tindak pidana yang lain hari dijatuhkan kepada terdakwa. Maksudnya, surat dakwaan penuntut umum bersifat alternatif, dan dari hasil pernya pembuktian yang diperoleh dalam persidangan pengadilan, kesalahan yang terbukti adalah dakwaan pengganti. Berarti apa yang didakwakan pada dakwaan primair tidak sesuai dengan kenyataan pembuktian dalam hal seperti ini, arti dan fungsi pembuktian merupakan penegasan tentang dakwaan yang tidak terbukti dan menghukumnya berdasar dakwaan tindak pidana yang telah terbukti.

Sehubungan dengan pengertian pembuktian, ada beberapa hal yang menjadi pertanyaan, yaitu kapan diperlukan pembuktian dalam suatu proses pemeriksaan perkara pidana? Apakah selamanya pembuktian perlu dalam sidang pengadilan? untuk melihat lebih jelas maksud pertanyaan yang dikemukakan, ada baiknya diambil perbandingan dengan pembuktian yang diatur dalam hukum acara perdata. Proses pemeriksaan persidangan pengadilan dalam perkara perdata telah menggariskan prinsip pembuktian diperlukan sepanjang terhadap apa yang dibantah secara tegas, apa-apa yang tidak dibantah oleh tergugat, dengan sendirinya dianggap telah terbukti kebenarannya. Dalam perkara perdata, posita yang diakui dan dibenarkan tergugat dianggap telah terbukti karena itu tidak perlu dibuktikan lagi oleh penggugat. Prinsip pembuktian yang demikian tidak dapat diterapkan dalam pemeriksaan perkara pidana. Penerapan pembuktian perkara pidana yang diatur dalam hukum acara pidana, pemeriksaan dalam rangka pembuktian tetap diperlukan sekalipun terdakwa mengakui tindak pidana yang didakwakan kepadanya. Seandainya terdakwa mengakui kesalahan yang didakwakan kepadanya, penuntut umum dan persidangan tetap berkewajiban untuk membuktikan kesalahan terdakwa dengan alat bukti yang lain, selain pengakuan bersalah dari terdakwa.

Meski ada pengakuan bersalah dari terdakwa sama sekali tidak melenyapkan kewajiban penuntut umum dan persidangan untuk menambah dan menyempurnakan pengakuan itu dengan alat bukti yang lain. Baik alat bukti keterangan saksi, keterangan ahli atau surat maupun dengan alat bukti petunjuk. Hal tersebut sesuai dengan penegasan yang dirumuskan dalam ketentuan Pasal 189 ayat (4) KUHAP, yang menyatakan: "Keterangan terdakwa saja atau pengakuan terdakwa tidak cukup untuk membuktikan bahwa ia bersalah melakukan perbuatan yang didakwakan kepadanya, melainkan harus disertai alat bukti yang lain."

Ketentuan itu sama dengan apa yang diatur dalam Pasal 308 HIR yang menegaskan: "Untuk dapat menghukum terdakwa, selain dari pada pengakuannya harus dikuatkan pula dengan alat-alat bukti yang lain".

Berdasarkan hal tersebut dapat disimpulkan bahwa Pasal 189 ayat (4) KUHAP mempunyai makna, pengakuan menurut KUHAP, bukan merupakan alat bukti yang mempunyai kekuatan pembuktian yang sempurna. Juga memiliki kekuatan pembuktian yang menentukan. Oleh karena pengakuan atau keterangan terdakwa bukan alat bukti yang memiliki kekuatan pembuktian yang sempurna dan menentukan, penuntut umum dalam persidangan tetapmempunyai kewajiban untuk membuktikan kesalahan terdakwa dengan alat bukti yang lain.

KUHAP sebagai acuan hukum acara pidana di Indonesia tidak mengenal keterangan atau pengakuan yang bulat dan murni. Ada atau tidak pengakuan terdakwa, pemeriksaan pembuktian kesalahan terdakwa tetap merupakan suatu kewajiban dalam sidang pengadilan. Hal mana sesuai dengan kebenaran yang hendak dicari dan ditemukan dalam proses suatu perkara pidana, kebenaran yang harus ditemukan dan diwujdkan dalam pemeriksaan perkara pidana adalah kebenaran sejati (materiil warheid). Oleh karena itu, pengakuan atau keterangan terdakwa saja belum dianggap sebagai perwujudan kebenaran sejati tanpa dikuatkan dengan alat bukti lain. Berbeda halnya dalam pemeriksaan perkara perdata kebenaran yang diwujudkan secara ideal adalah kebenaran sejati, tetapi jika kebenaran sejati tidak ditemukan, hakim dibenarkan mewujudkan kebenaran formal.

Melengkapi uraian pembuktian perlu juga dibicarakan mengenai apa yang dirumuskan dalam Pasal 184 ayat (2) KUHAP yang berbunyi hal yang secara umum sudah diketahui tidak perlu dibuktikan. Rumusan pasal 184 ayat (2) KUHAP ini selalu disebut dengan istilah notoire feiten notorious yang berarti setiap hal yang sudah umum diketahui tidak lagi perlu dibuktikan dalam pemeriksaan sidang pengadilan. Mengenai pengertian hal yang secara 
umum diketahui ditinjau dari segi hukum yaitu penjelasan mengenai keadaan yakni hal ikhwal atau peristiwa yang diketahui umum bahwa hal ikhwal atau peristiwa itu memang sudah demikian hal yang sebenarnya atau sudah semestinya demikian halnya. Dalam pengertian lain berupa perihal kenyataan dan pengalaman yang akan selamanya dan selalu akan mengakibatkan kesimpulan yang demikian yaitu kesimpulan yang didasarkan pengalaman umum ataupun berdasarkan pengalaman hakim sendiri bahwa stiap peristiwa dan kedaan yang seperti itu dapat menimbulkan akibat yang pasti demikian. Dalam hal-hal seperti ini persidangan pengadilan tidak perlu lagi membuktikan, karena keadaan itu dianggap merupakan secara umum sudah diketahui.

Dalam hukum acara perdata, notoire feiten tidak perlu dibuktikan dan dianggap merupakan penilain pembuktian yang tidak takluk pada pemeriksaan tingkat kasasi. Bagaimana halnya dalam hukum acara pidana diatur dalam KUHAP? Apakah hal yang secara umum sudah diketahui tidak memerlukan pembuktian lagi? Memang demikian halnya sebagai mana yang ditegaskan dalam Pasal 184 ayat (2) KUHAP oleh karena itu, dalam penerapan notoire feiten majelis hakim dapat menarik dan mengambilnya sebagai suatu kenyataan yang dapat dijadikan sebagai fakta tanpa membuktikannya lagi, akan tetapi kenyataan yang diambil hakim dari notoire feiten tidak bisa berdiri sendiri tanpa dikuatkan oleh alat bukti yang lain. Kenyataan yang ditarik dan diambil hakim dengan notoire feiten tidaklah cukup membuktikan kesalahan yang didakwakan kepada terdakwa, karena pada hakikatnya notoire feiten tidak tergolong alat bukti yang diakui oleh undang-undang sebagaimana yang disebut secara limitatif dalam Pasal 184 ayat (1) KUHAP. Hal yang secara umum sudah diketahui hanyalah merupakan penilaian terhadap sesuatu pengalaman dan kenyataan tertentu saja bukan sesuatu yang dapat membuktikan kesalahan yang terdakwa secara menyeluruh.

\section{Alat-Alat Bukti dalam Hukum Acara Pidana Indonesia}

Berdasarkan ketentuan Pasal 184 ayat (1) KUHAP, secara limitatif sebagai alat bukti yang sah adalah:

\section{Alat Bukti Keterangan Saksi}

KUHAP telah memberikan batasan pengertian saksi, yaitu orang yang dapat memberikan keterangan guna kepentingan penyidikan, penuntutan dan peradilan tentang suatu perkara pidana yang ia dengar sendiri, ia lihat sendiri dan ia alami sendiri dengan menyebut alasan dari pengetahuannya itu (Pasal 1 angka 26 KUHAP). Sedangkan keterangan saksi adalah satu alat bukti dalam perkara pidana yang berupa keterangan saksi mengenai suatu peristiwa pidana yang ia dengar sendiri, ia lihat sendiri dan ia alami sendiri dengan meyebut alasan dari pengetahuannya (Pasal 1 angka 27 KUHAP).

Isi yang diterangkan saksi adalah segala sesuatu yang ia dengar sendiri, ia lihat sendiri dan ia alami sendiri. Keterangan mengenai segala sesuatu yang sumbernya diluar 3 (tiga) sumber di atas, tidaklah mempunyai nilai atau kekuatan pembuktian. Ketentuan ini menjadi suatu prinsip pembuktian dengan menggunakan alat bukti keterangan saksi.

Keterangan saksi haruslah disertai alasan dari sebab apa ia mengetahui tentang sesuatu yang ia terangkan. Artinya, isinya keterangannya baru berhargadanmemilikinilaipembuktianapabilasetelah memberikan keterangan ia kemudian menerangkan tentang sebab-sebab dari pengetahuannya tersebut. Hal ini pun merupakan prinsip umum alat bukti keterangan saksi dalam hal pembuktian.

Di dalam batasan pengertian saksi dan keterangan saksi sebagaimana telah diuraikan di atas, terdapat mengenai syarat yakni apa yang diterangkan adalah mengenai hal yang dilihat, didengar dan dialami saksi sendiri, apabila syarat itu tidak dipenuhi maka keterangan saksi tersebut tidak bernilai pembuktian, karena bukan sebagai alat bukti yang sah. Oleh karena itu, tidak dapat dipertimbangkan sebagai alat bukti perkara pidana. Tentu saja tidak dapat digunakan untuk membentuk keyakinan hakim.

Syarat keterangan saksi agar keterangannya itu menjadi sah dan berharga, sehingga dapat digunakan sebagai salah satu dasar pertimbangan hakim dalam hal membentuk keyakinannya, dapat terletak pada beberapa hal antara lain:

a. Mengenai Kualitas Pribadi Saksi - Kualitas pribadi yang dimaksud adalah kualitas saksi dalam hubungan dengan terdakwa. Dalam hal ini ada 2 (dua) kemungkinan. Kemungkinan pertama saksi tidak ada hubungan keluarga apapun denga terdakwa. Kemungkinan kedua saksi masih ada hubungan keluarga dengan terdakwa.

Mengenai batas-batas hubungan kekeluargaan ini, Pasal 168 KUHAP melarang seseorang untuk didengar keterangannya dan dapat mengundurkan diri sebagai saksi, jika kualitas saksi tersebut berada dalam hubungan keluarga sebagai berikut: (1) Keluarga sedarah atau semenda dalam garis lurus keatas atau kebawah sampai derajat ketiga dari terdakwa atau yang bersama-sama dengan terdakwa; (2) Saudara dari terdakwa atau yang bersama-sama sebagai terdakwa, saudara ibu atau saudara bapak, juga mereka yang mempunyai 
hubungan karena perkawinan dan anak-anak saudara terdakwa sampai derajat ketiga; dan (3) Suami atau istri terdakwa meskipun sudah bercerai atau yang bersama-sama sebagai terdakwa.

b. Hal Apa yang Diterangkan Saksi - Bahwa ada 2 (dua) syarat yang menyangkut keterangan saksi dimuka sidang pengadilan yang tidak bisa dipisahkan, agar keterangan itu bernilai dan berharga pembuktian yang dapat dipertimbangkan untuk membentuk keyakinan hakim ialah: (1) Mengenai sumber pengetahuan saksi dari apa yang menjadi isi yang diterangkan; dan (2) Mengenai substansi isinya keterangan.

c. Alasan Apa Saksi Mengetahui tentang Apa yang Ia Terangkan - Apa yang dimaksud dengan alasan adalah segala sesuatu yang menjadi sebab mengapa seorang saksi melihat dan mendengar atau mengalami tentang peristiwa yang diterangkan saksi. Sebab ini haruslah rational artinya suatu sebab yang dapat diterima akal sehat.

d. Syarat Mengucap Sumpah atau Janji - Sejak masih berlakunya HIR (Pasal 265 ayat 3), kepercayaan akan kebenaran suatu keterangan saksi dimuka persidangan diletakkan pada adanya sumpah, yang diucapkan sebelum memberikan keterangan atau sesudah memberikan keterangan. Ketentuan dalam Pasal 265 ayat (3) HIR seluruhnya diadopsi kedalam KUHAP. Pasal 160 ayat (3) KUHAP mewajibkan pada saksi sebelum memberikan keterangan untuk terlebih dulu mengucapkan sumpah atau janji menurut cara agamanya, yang isinya sumpah atau janji bahwa ia akan memberikan keterangan yang sebenarnya dan tidak lain daripada yang sebenarnya. Cara penyumpahan ini disebut dengan promissoris, artinya sanggup berkata yang benar. Akan tetapi, apabila pengadilan menganggap perlu penyampaian sumpah tidak dilakukan sebelum memberikan keterangan, melainkan diberikan setelah saksi memberikan keterangan (Pasal 160 ayat (4)). Cara penyumpahan yang kedua ini disebut assetoris, dan tidak dikenal HIR.

e. Syarat Adanya Hubungan Keterangan Saksi dengan Keterangan Saksi Lain atau Alat Bukti Lain - Suatu fakta yang didapat dariketerangan seorang saksi tidaklah cukup, dalam arti tidak bernilai pembuktian apabila tidak didukung oleh fakta yang sama (disebut bersesuaian) yang didapat dari saksi lain atau alat bukti lainnya. Pasal 185 ayat (2) menentukan bahwa keterangan seorang saksi saja tidak cukup untuk membuktikan bahwa terdakwa bersalah terhadap perbuatan yang didakwakan kepadanya.

Mengikuti ketentuan ini maka suatu fakta yang didapat dari keterangan saksi yang satu agar menjadi berharga haruslah didukung dengan keterangan saksi yang lain, atau didukung oleh alat bukti lain. Maksudnya didukung adalah keterangan satu saksi harus sama, yang dalam praktik disebut bersesuaian dengan keterangan saksi yang lain atau alat bukti yang lain. Artinya, keterangan satu saksi saja tidaklah bernilai pembuktian apabila tidak didukung atau ada persesuaian dengan keterangan saksi yang lain atau alat bukti yang lain.Dengan demikian, sudah dapat memenuhi syarat minimal pembuktian, yakni sekurang-kurang dari dua alat bukti yang sah sebagaimana disyaratkan Pasal 183 KUHAP.

\section{Alat Bukti Keterangan Ahli}

Dalam praktek alat bukti ini disebut alat bukti saksi ahli. Tentu saja pemakaian istilah saksi ahli tidak benar. Karena perkataan saksi mengandung pengertian yang berbeda dengan ahli atau keterangan ahli. Bahwa isi keterangan yang disampaikan saksi adalah segala sesuatu yang ia dengar sendiri, ia lihat dan ia alami sendiri (Pasal 1 angka 26 KUHAP). Pada keterangan saksi haruslah diberikan alasan dari sebab pengetahuannya itu (Pasal 1 angka 27 KUHAP). Sedangkan seorang ahli memberikan keterangan bukan mengenai segala hal yang dilihat, didengar dan dialaminya sendiri, tetapi mengenai hal-hal yang menjadi atau dibidang keahliannya yang hubungannya dengan perkara yang sedang diperiksa. Keterangan ahli tidak perlu diperkuat dengan alasan sebab keahliannya atau pengetahuannya sebagaimana pada keterangan saksi. Apa yang diterangkan saksi adalah hal mengenai kenyataan atau fakta. Akan tetapi, yang diterangkan ahli adalah suatu penghargaan dari kenyataan dan atau kesimpulan atas penghargaan itu berdasarkan keahlian seorang ahli. ${ }^{7}$

Keterangan ahli adalah keterangan yang diberikan seorang yang memiliki keahlian khusus tentang hal yang diperlukan untuk membuat terang suatu perkara pidana guna kepentingan pemeriksaan (Pasal 1 angka 28). Apa isi yang harus diterangkan oleh ahli, serta syarat apa yang harus dipenuhi agar keterangan ahli mempunyai nilai tidaklah diatur dalam KUHAP, tetapi dapat dipikirkan bahwa berdasarkan Pasal 1 angka 28 KUHAP, secara khusus ada 2 syarat dari keterangan seorang ahli ialah: (a) Bahwa apa diterangkan haruslah mengenai segala sesuatu yang masuk dalam ruang lingkup keahliannya; (b) Bahwa yang diterangkan mengenai keahliannya itu adalah berhubungan erat dengan perkara pidana yang sedang diperiksa.

\footnotetext{
${ }^{8}$ Sudikno Mertokusumo, op cit, hlm. 111.
} 
3. Alat Bukti Surat.

KUHAP sedikit sekali mengatur tentang alat bukti surat. Hanya dua pasal, yakni Pasal 184 dan secara khusus Pasal 187. HIR juga demikian, secara khusus diatur dalam tiga pasal saja, yakni Pasal 304, 305,306 . Walaupun hanya 3 pasal yang isinya hampir sama dengan pasal 187 KUHAP, dalam Pasal 304 HIR, disebutkan bahwa aturan tentang nilaikekuatan dari alat bukti surat-surat pada umumnya dan suratsurat resmi (openbaar) dalam hukum acara perdata harus diturut dalam hukum acara pidana. Dengan demikian, mengenai surat-surat pada umumnya (maksudnya di bawah tangan) dan surat-surat resmi(akta otentik) mengenai nilai pembuktiannya dalam perkara pidana harus menurut hukum acara perdata. Sayang ketentuan seperti Pasal 304 HIR ini, tidak ada dalam KUHAP.

Tiga jenis surat yang dibuat diatas sumpah atau dikuatkan dengan sumpah tersebut adalah:

a. berita acara dan surat lain dalam bentuk resmi yang dibuat oleh pejabat umum yang berwenang atau yang dibuat dihadapannya, yang memuat keterangan tentang kejadian atau keadaan yang didengar, dilihat atau dialaminya sendiri, disertai dengan alasan yang jelas dan tegas tentang keterangannya itu;

b. surat yang dibuat menurut ketentuan peraturan perundang-undangan atau surat yang dibuat oleh pejabat mengenai hal yang termasuk dalam tata laksana yang menjadi tanggung jawabnya dan diperuntukkan bagi pembuktian sesuatu hal atau sesuatu keadaan;

c. surat keterangan dari seorang ahli yang memuat pendapat berdasarkan keahliannya mengenai sesuatu hal atau sesuatu keadaan.

\section{Alat Bukti Petunjuk}

Bukti petunjuk ini adalah berupa pemikiran atau pendapat hakim yang dibentuk dari hubungan atau persesuaianalat bukti yang ada dan dipergunakan dalam sidang, maka sifat subyektivitas hakim lebih dominan. Oleh karena itu, Pasal 188 ayat (3) KUHAP mengingatkan hakim agar dalam menilai kekuatan alat bukti petunjuk dalam setiap keadaan tertentu harus dilakukan dengan arif dan bijaksana, setelah hakim memeriksa dengan cermat dan seksama yang didasarkan hati nuraninya.

\section{Alat Bukti Keterangan Terdakwa}

Diantara 5 (lima) alat bukti yang disebut dalam Pasal 184 ayat (1) KUHAP, alat bukti keterangan terdakwalah yang acap kali diabaikan oleh hakim.
Hal ini dapatlah dimaklumi, karena berbagai sebab, antara lain ialah:

a. Seringkali keterangan terdakwa tidak bersesuaian dengan isi dari alat-alat bukti yang lain, misalnya, keterangan saksi. Tidak menerangkan hal-hal yang memberatkan atau merugikan terdakwa sendiri adalah sesuatu sifat manusia (manusiawi). Bahwa setiap orang selalu ada kecenderungan untuk menghindari kesusahanatau kesulitan bagi dirinya sendiri. Untuk itu ia terpaksa berbohong;

b. Pada diri terdakwa memiliki hak untuk bebas berbicara termasuk yang isinya tidak benar. Berhubung terdakwa yang memberi keterangan yang tidak benar tidak diancam sanksi pidana sebagaimana saksi memberikan keterangan yang isinya tidak benar. Karena terdakwa tidak disumpah sebelum memberikan keterangan, sebagaimana saksi sebelum memberikan keterangan. Pada sumpah diletakkan kepercayaan kebenaran atas keterangan yang diberikan di sidang pengadilan. Pada sanksi pidana diletakkan kekuatan paksaan agar seorang saksi memberikan keterangan yang benar;

c. Pengabaian oleh hakim biasanya terhadap keterangan terdakwa yang berisi penyangkalan terhadap dakwaan. Pegabaian hakim dapatlah diterima, mengingat menurut KUHAP penyangkalan terdakwa bukanlah menjadi bagian isi alat bukti keterangan terdakwa.

Ketentuan keterangan terdakwa yang sah ialah keterangan yang diberikan di muka sidang peng-adilan, keterangan yang sah dan mempunyai nilai pembuktian yang dapat dipergunakan hakim bersama alat bukti lainnya dalam pertimbangan hukumnya atau dalam usaha hakim membentuk keyakinan untuk menari amar putusan akhir perkara yang diadilinya. Oleh karena itu, alat bukti keterangan terdakwa di dalam BAP tidak dapat dipertimbangkan sebagai dasar untuk membentuk keyakinan hakim. Keterangan terdakwa diluar sidang pengadilan juga mengandung nilai, tetapi bukan bernilai dalam rangka untuk membentuk keyakinan hakim, melainkan bernilai sebagai bantuan (membantu) untuk menemukan bukti di sidang, asalkan keterangan diluar sidang itu didukung oleh suatu alat bukti yang sah sepanjang mengenai hal yang didakwakan berdasarkan Pasal 189 ayat (2) KUHAP.

\section{Hukum Pembuktian dalam Perspektif Hukum Acara Perdata}

Dalam persidangan perdata di pengadilan negeri, berdasarkan hukum acara perdata Indonesia ada bagian acara persidangan yaitu pembuktian. Terdapat beberapa teori tentang beban pembuktian yang dapat 
merupakan pedoman bagi hakim dalam memeriksa dan memutus perkara,yaitu ${ }^{8}$ :

1. Teori Pembuktian yang Bersifat Menguatkan Belaka (bloot affirmatief) - Siapa yang mengemukakan sesuatu harus membuktikannya dan bukan yang mengingkari atau menyangkalnya. Dasar hukum dari teori ini ialah pendapat bahwa hal-hal yang negatif tidak mungkin dibuktikan (negative non sun probanda). Peristiwa negatif tidak dapat menjadi dasar dari suatu hak, sekalipun pembuktiannya mungkin, hal ini tidaklah penting dan oleh karena itu tidak dapat dibebankan kepada seseorang. Teori "bloot affirmatief" ini sekarang sudahditinggalkan.

2. Teori Hukum Subyektif - Suatu proses perdata itu selalu merupakan pelaksanaan hukum subyektif atau bertujuan mempertahankan hukum subyektif, dan siapa yang mengemukakan atau mengaku mempunyai sesuatu hak harus membuktikannya. Dalam hal ini penggugat tidak perlu membuktikan semuanya. Untuk mengetahui peristiwa mana yang harus dibuktikan dibedakan antara peristiwa

- peristiwa umum dan peristiwa-peristiwa khusus. Yang terakhir ini dibagi lebih lanjut menjadi peristiwa khusus yang bersifat menimbulkan hak (rechtserzeugende tatsachen), peristiwa khusus yang bersifat menghalang-halangi timbulnya hak (rechtshindernde tatsachen) dan peristiwa khusus yang bersifat membatalkan hak (rechtsvernichtende tatsachen).

Penggugat berkewajiban membuktikan adanya peristiwa-peristiwa khusus yang bersifat menimbulkan hak. Tergugat harus membuktikan tidak adanya peristiwa-peristiwa (syarat-syarat) umumdanadanyaperistiwa-peristiwakhususyang bersifat menghalang-halangi dan yang bersifat membatalkan. Sebagai contoh dapat dikemukakan misalnya, kalau penggugat mengajukan tuntutan pembayaran harga penjualan, maka penggugat harus membuktikan adanya persesuaian kehendak, harga serta penyerahan, sedangkan kalau tergugat menyangkal gugatan penggugat dengan menyatakan telah dilakukan pembayaran maka tergugatlah yang harus membuktikannya.

Teori ini hanya dapat memberi jawaban apabila gugatan penggugat didasarkan atas hukum subyektif. Ini tidak selalu demikian, misalnya pada gugat cerai. Keberatan-keberatan lainnya ialah teori ini terlalu banyak kesimpulan yang abstrak dan tidakmemberi jawaban atas persoalan-

\footnotetext{
${ }^{8}$ Sudikno Mertokusumo, op cit, hlm. 111.
}

persoalan tentang beban pembuktian dalam sengketa yang bersifat prosesuil. Didalam praktek teori ini sering menimbulkan ketidakadilan. Hal ini diatasi dengan memberi kelonggaran kepada hakim intuk mengadakan pengalihan beban pembuktian.

3. Teori Hukum Obyektif-Menurut teori ini, mengajukan tuntutan hak atau gugatan berarti bahwa penggugat minta kepada hakim agar hakim menerapkan ketentuan-ketentuan hukum obyektif terhadap peristiwa yang diajukan. Oleh karena itu penggugat harus membuktikan kebenaran daripada peristiwa yang diajukannya dan kemudian mencari hukum obyektifnya untuk diterapkan pada peristiwa tersebut, misalnya harus mengemukakan adanya suatu persetujuan, harus mencari dalam undang-undang dan syaratsyarat sahnya persetujuan berdasarkan Pasal 1320 KUHPerdata dan kemudian memberi pembuktiannya, tidak perlu membuktikan adanya cacat dalam persesuaian kehendak, sebab hal itu tidak disebutkan dalam Pasal 1320 KUHPerdata. Tentang adanya cacat ini harus dubuktikan oleh pihak lawan. Hakim yang tugasnya menerapkan hukum obyektif pada peristiwa yang diajukan oleh para pihak hanya dapat mengabulkan gugatan apabila unsur-unsur yang ditetapkan oleh hukum obyektif ada. Jadi atas dasar isi hukum obyektif yang diterapkan dapat ditentukan pembagian beban pembuktian. Teori ini sudah tentu tidak akan dapat menjawab persoalan-persoalan yang tidak diatur oleh undang-undang. Selanjutnya teori ini bersifat formalistis.

4. Teori Hukum Publik - Menurut teori ini mencari kebenaran suatu peristiwa di dalam peradilan merupakan kepentingan publik. Oleh karena itu hakim harus diberikan wewenang yang lebih besar untuk mencari kebenaran. Disamping itu para pihak ada kewajiban yang sifatnya hukum publik, untuk membuktikan dengan segala macam alat bukti. Kewajiban ini harus disertai sanksi pidana.

5. Teori Hukum Acara - Asas auditu et alteram partem atau juga asas kedudukan prosesuil yang sama daripada para pihak di muka hakim merupakan asas pembagian beban pembuktian menurut teori ini. Hakim harus membagi beban pembuktian berdasarkan kesamaan kedudukan para pihak. Asas kedudukan prosesuil yang sama daripada para pihak membawa akibat bahwa kemungkinan untuk menang bagi para pihak harus 
sama. Oleh karena itu hakim harus membebani para pihak dengan pembuktian secara seimbang atau patut. Kalau penggugat menggugat tergugat mengenai perjanjian jual beli, maka sepatutnyalah kalau penggugat membuktikan tentang adanya jual beli itu dan bukannya tergugat yang harus membuktikan tentang tidak adanya perjanjian tersebut antara penggugat dan tergugat. Kalau tergugat mengemukakan bahwa ia membeli sesuatu dari penggugat, tetapi bahwa jual beli itu batal karena kompensasi, maka tergugat harus membuktikan bahwa ia mempunyai tagihan kepada penggugat. Penggugat dalam hal ini tidak perlu membuktikan bahwa ia tidak mempunyai hutang pada tergugat. Kiranya sudah sepatutnyalah kalau yang harus dibuktikan itu hanyalah hal-hal yang positif saja, yaitu adanya suatu peristiwa dan bukannya tidak adanya suatu peristiwa. Demikian pula siapa yang siapa yang menguasai barang tidak perlu membuktikan bahwa ia berhak atas barang tersebut, sebaiknya siapa yang hendak menuntut suatu barang dari orang lain ia harus membuktikan bahwa ia berhak atas barang tersebut. Teori-teori pembuktian tersebut selalu digunakan oleh para pihak baik penggugat maupun tergugat, bahkan hakim dalam pemeriksaan fakta-fakta hukum dalam persidangan perdata di pengadilan negeri.

\section{Alat-Alat Bukti dalam Hukum Acara Perdata}

Berdasarkan ketentuan Pasal 164 HIR dan 1866 KUHPerdata, secara limitatif sebagai alat bukti yang sah adalah:

1. Alat Bukti Tulisan/Surat - Surat sebagai alat pembuktian tertulis dapat dibedakan dalam akta dan surat bukan akta, kemudian akta masih dapat dibedakan lagi dalam akta otentik dan akta dibawah tangan. Jadi, dalam hukum pembuktian dikenal tiga jenis surat yaitu:

(a) Akta Otentik Sebagaimana telah disebutkan di atas bahwa akta dapat dibedakan dalam akta otentik dan akta dibawah tangan. Berdasarkan penjelasan Pasal 165 HIR yang berbunyi: "akta otentik adalah suatu surat yang dibuat oleh atau dihadapan pegawai umum yang berkuasa membuatnya, mewujudkan bukti yang cukup bagi kedua belah pihak dan ahli warisnya serta sekalian orang yang mendapat hak daripadanya yaitu tentang segala hal, yang tersebut didalam surat itu dan juga tentang yang tercantum dalam surat itu sebagai pemberitahuan sah saja; tetapi yang tersebut kemudian itu hanya sekedar yang diberitahukan itu langsung berhubung dengan pokok dalam akta itu". Berdasarkan definisi yuridis tersebut maka dapat disimpulkan bahwa yang disebut sebagai akta otentik harus memenuhi unsur-unsur sebagai berikut: (1) Berbentuk surat atau tertulis yang dibuat oleh atau dihadapan pegawai yang berwenang untuk membuatnya, seperti notaris, camat dan lain-lain; (2) Isinya merupakan suatu bukti yang cukup kuat bagi pihak-pihak yang membuatnya dan juga bagi para ahli warisnya atau pihak lainnya; (3) Selain itu isinya juga suatu pemberitahuan yang sah.

(b) Akta Di Bawah Tangan - Definisi akta di bawah tangan dapat ditemukan dalam Pasal 1874 ayat (1) KUHPerdata yang mengatakan: "Sebagai tulisan-tulisan di bawah tangan dianggap akta-akta yang ditandatangani di bawah tangan, surat-surat, register-register, surat-surat urusan rumahtangga dan lain-lain tulisan yang dibuat tanpa perantaraan seorang pegawai umum" Dari ketentuan Pasal 1878 KUHPerdata terdapat kekhususan akta di bawah tangan yaitu: (1) Akta harus seluruhnya ditulis dengan tangan si penandatangan sendiri, yang harus ditulis dengan tangannya si penanda tangan adalah suatu penyebutan yang membuat jumlah atau besarnya barang/uang yang terhutang;

(2) Akta harus ditandatangani oleh pihak-pihak yang membuatnya; (3) Tanpa perantara seorang pegawai umum.

Alat bukti tertulis atau surat dalam bentuk akta tersebut yang diajukan dalam persidangan haruslah memiliki kekuatan pembuktian. Adapun kekuatan pembuktian akta adalah: (1) Kekuatan Pembuktian Lahir - suatu kekuatan pembuktian yang didasarkan atas keadaan lahir, bahwa suatu surat yang kelihatannya seperti akta, diterima/ sanggup seperti akta dan diperlakukan sebagai akta, sepanjang tidak terbukti kebalikannya. Jadi surat itu harus diperlakukan seperti akta, kecuali ketidakotentikan akta itu dapat dibuktikan oleh phak lain, misalnya dapat dibuktikan bahwa tanda tangan yang didalam akta dipalsukan. Dengan demikian, pembuktiannya bersumber pada kenyataan; (2) Kekuatan Pembuktian For-mal —suatu kekuatan pembuktian yang didasarkan atas benar atau tidaknya pernyataan yang ditandatangani dalam akta bahwa oleh 
penanda tangan akta diterangkan apa yang tercantum di dalam akta. Misalnya, antara A dan B yang melakukan jual beli, mengakui bahwa tanda tangan yang tertera dalam akta itu benar, jadi pengakuan mengenai pernyataan terjadinya peristiwa itu sendiri, bukan mengenai isi dari pernyataan itu. Atau dalam hal menyangkut pertanyaan, "benarkah bahwa ada pernyataan para pihak yang menandatangani'”? Dengandemikian, berarti pembuktiannya bersumber atas kebiasaan dalam masyarakat, bahwa orang menandatangani suatu surat itu untuk menerangkan bahwa hal- hal yang tercantum di atas tanda tangan tersebut adalah keterangannya; (3) Kekuatan Pembuktian Material - suatu kekuatan pembuktian yang didasarkan atas benar atau tidaknya isi dari pernyataan yang ditandatangani dalam akta, bahwa peristiwa hukum yang diyatakan dalam akta itu benar-benar telah terjadi, memberi kepastian tentang materi akta. Misalnya A dan B mengakui benar bahwa jual beli itu telah terjadi. Dengan demikian, berarti pembuktiannya bersumber pada keinginan agar orang lain menganggap isi keterangannya dan untuk siapa isi keterangan itu berlaku, sebagai benar dan bertujuan untuk mengadakan bukti buat dirinya sendiri. Maka dari sudut kekuatan pembuktian material, suatu akta hanya memberikan bukti terhadap si penanda tangan. Seperti halnya suatu surat yang berlaku timbal balik juga membuktikan terhadap dirinya sendiri dari masing-masing si penanda tangan.

(c) Surat Bukan Akta Pengaturan - Definisi mengenai surat yang bukan akta tidak ditentukan dan diatur secara tegas dalam HIR. Walaupun surat-surat yang bukan akta ini sengaja dibuat oleh yang bersangkutan, tapi pada asasnya tidak dimaksudkan sebagai alat pembuktian di kemudian hari. Oleh karena itu surat-surat yang demikian itu dapat dianggap sebagai petunjuk kearah pembuktian. Dengan demikian surat bukan akta untuk dapat mempunyai kekuatan pembuktian, sepenuhnya bergantung kepada penilaian hakim sebagaimana ditentukan dalam Pasal 1881 ayat (1) KUHPerdata yang mengatur sebagai berikut: "Register-register dan suratsurat urusan rumah tangga tidak memberikan pembuktian untuk keuntungan si pembuatnya; adalah register-register dan surat-surat itu itu menyebutkan dengan tegas tentang suatu pembayaran yang telah diterima;

2e. apabila surat-surat itu dengan tegas menyebutkan bahwa catatan yang telah dibuat adalah untuk memperbaiki suatu kekurangan di dalam sesuatu alasan hak bagi seseorang untuk keuntungan siapa surat itu menyebutkan suatu perikatan.

\section{Alat Bukti Saksi}

Alat bukti yang kedua adalah bukti saksi yaitu orang yang memberikan kesaksiannya di dalam persidangan pengadilan. Kesaksian adalah kepastian yang diberikan kepada hakim di persidangan tentang peristiwa yang disengketakan dengan jalan pemberitahuan secara lisan dan pribadi oleh orang yang bukan salah satu pihak dalam perkara, yang dipanggil di persidangan ${ }^{9}$.

Dengan demikian keterangan yang dikemukakan oleh saksi itu harus hal-hal tentang peristiwa atau kejadian yang dilihat atau dialami sendiri. Seseorang yang melihat atau mengalami sendiri kejadian itu memang ada dengan sengaja diajak untuk menyaksikannya, akan tetapi ada juga yang hanya secara kebetulan saja.

Saksi yang dipanggil dimuka siding pengadilan mempunyai kewajiban-kewajiban menurut hukum, yaitu antara lain:

a. Kewajiban untuk menghadap atau datang memenuhi pangilan pengadilan untuk memberikan keterangannya dalam persidangan. Dengan syarat setelah dipanggil dengan patut dan sah menurut hukum (Pasal 139, 140, 141 HIR);

b. Kewajiban untuk bersumpah sebelum mengemukakan keterangan. Sumpah tersebut dilakukan menurut agamanya dan bagi suatu agama yang melarang sumpah dapat diganti dengan mengucapkan janji (Pasal 147, 148 HIR);

c. Kewajiban untuk memberikan keterangan yang benar (Pasal 148 HIR).

Hakim dalam penilaian alat bukti saksi berdasarkan pasal 1908 KUHPerdata dan Pasal 172 HIR, berdasarkanketentuantersebuthakimdiharuskan memperhatikan kesamaan antara keterangan para saksi. Persesuaian antara keterangan-keterangan dengan apa yang diketahui dan dengan segi lain tentang perkara, sebab-sebab yang mendorong para

merupakan pembuktian terhadap si pembuatnya:

1e. di dalam segala hal dimana surat-surat 
saksi mengemukakan keterangannya, pada cara hidupnya, kesesuaiannya, kedudukan para saksi, dan segala apa yang berhubungan dengan keterangan yang di kemukakan.

Pada asasnya semua orang cakap dapatbertindak sebagai saksi. Dan apabila telah dipanggil dengan sah dan patut menurut hukum, wajiblah ia mengemukakan kesaksiannya di muka pengadilan sebagaimana diatur dalam Pasal 1909 ayat (1) KUHPerdata dan Pasal 139 HIR. Bahkan apabila tidak mau datang atau datang tetapi tidak mau memberikan kesaksian, ia dapat dikenakan sanksi. Walaupun demikian, terhadap asas tersebut dibuka suatu pengecualian atau penyimpangan yaitu:

Golongan yang secara mutlak dianggap tidak mampu bertindak sebagai saksi yaitu:

1) Keluarga sedarah dan keluarga semenda menurut keturunan yang lurus dan salah satu pihak (Pasal 145 ayat (1) sub 1e HIR, Pasal 1910 ayat (1) KUHPerdata). Larangan ini oleh pembentuk undang-undang didasarkan pada pertimbangan bahwa: (a) Mereka itu tidak akan cukup objektif dalam memberi keterangan; (b) Untuk menjaga agar hubungan kekeluargaan mereka tetap baik; (c) Untuk mencegah terjadinya pertengkaranatau timbulnya rasa dendam di antara mereka.

Walaupun begitu dalam perkara-perkara tertentu mereka mampu untuk bertindak sebagai saksi seperti: (a) Dalam perkara-perkara mengenai kedudukan keperdataan salah satu pihak; (b) Dalam perkara-perkara mengenai pemberian nafkah, termasuk pembiayaan, pemeliharaan, dan pendidikan anak yang belum dewasa; (c)

Dalam perkara mengenai alasan-alasan yang menyebabkan pembebasan atau pemecatan dari kekuasaan orang tua atau perwalian; (d) Dalam perkara-perkara mengenai suatu persetujuan perburuhan (Pasal 145 ayat (2) HIR, 1910 ayat (2) KUHPerdata).

2) Suami atau istri salah satu pihak meskipun sudah bercerai (Pasal 145 ayat (1) sub 2e HIR, Pasal 1910 ayat (1) KUHPerdata);

3) Golongan yang secara relatif dianggap tidak mampu bertindak sebagai saksi yaitu: (a) Anakanak yang belum mencapai umur 15 tahun(Pasal 145ayat (1) sub 3e jo ayat (4) HIR, Pasal 1912 ayat (1) KUHPerdata); (b) Orang gila atau sakit ingatan, sekalipun kadang-kadang ingatannya terang (Pasal 145 ayat (1) sub 4c HIR, Pasal 1912 ayat (1) KUHPerdata. Dalam hal ini pasal 1912 ayat (2) KUHPerdata selanjutnya menentukan bahwa bagi mereka, hakim bebas untuk mendengar keterangannya dengan tidak di bawah sumpah. Dan keterangan-keterangan mereka hanya dianggap sebagai penjelasan belaka.

4) Orang yang karena permintaanya sendiri dibebaskan dari kewajibannya sebagai saksi, yang termasuk dalam golongan ini ialah: (a) Saudara laki-laki atau perempuan dan ipar lakilaki atau perempuan dari salah satu pihak; (b) Keluarga sedarah menurut keturunan yang lurus dan saudara laki-laki atau istri salah satu pihak; (c) Orang yang karena martabat, pekerjaan atau jabatan yang sah, diwajibkan merahasiakan, akan tetapi semata-mata hanya mengenai hal-hal yang dipercayakan padanya (Pasal 146 HIR, Pasal 1909 ayat (2) KUHPerdata)

Orang yang berkedudukan sebagai saksi memiliki kewajiban-kewajiban antara lain:

a. Kewajiban Untuk Menghadap

Didalam proses pemeriksaan suatu perkara di persidangan pengadilan negeri pada asasnya diperlukan adanya saksi. Pada pasal 121 ayat (1) HIR ditentukan bahwa sebelum perkara diperiksa di muka sidang pengadilan negeri, pengadilan atau hakim menyuruh memanggil para pihak dan saksi untuk menghadap pada hari sidang yang telah ditentukan, akan tetapi apabila dengan aturan pasal 121 ayat (1) HIR saksi tidak dapat menghadap karena tidak mau atau sebab lainnya, sedangkan kesaksiannya itu benar dibutuhkan untuk meneguhkan kebenaran tuntutan penggugat atau perlawanan tergugat, maka hakim menyuruh memanggil saksi agar menghadap di hari persidangan yang akan datang, sebagaimana diatur dalam Pasal 139HIR.

b. Kewajiban Untuk Bersumpah

Jika saksi yang dipanggil telah memenuhi panggilan dan tidak mengundurkan diri sebagai saksi, maka sebelum mengemukakan keterangannya ia harus disumpah menurut agamanya, ketentuan ini diatur dalam Pasal 147 HIR dan Pasal 1911 KUHPerdata.

c. Kewajiban Memberi Keterangan

Sebagaimana diuraian tentang kewajiban untuk bersumpah bagi saksi, yaitu bahwa apabila ia telah datang menghadap dan telah pula disumpah akan tetapi tidak mau memberi keterangan, maka dapat ditahan dalam penjara atau permintaan dan biaya pihak yang meminta untuk itu. 
Saksi yang telah datang menghadap dan telah pula disumpah di muka persidangan wajib memberikan keterangannya. Apabila ada pertanyaan-pertanyaan yang diajukan kepada saksi harus disampaikan lebih dahulu kepada hakim. Yang berkepentingan tidak boleh langsung melakukan tanya jawab kepada saksi melainkanmelaluihakimlahtanyajawabitudilakukan. Hakim dapat menolak pertanyaan-pertanyaan yang tidak ada hubungan dengan perkara (Pasal 150 ayat (1) HIR). Saksi yang mengemukakan keterangan di depan sidang akan dicatat di dalam berita acara persidangan oleh panitera (Pasal 152HIR).

\section{Bukti Persangkaan}

Mengenai bukti persangkaan di dalam HIR tidak dijelaskan, akan tetapi hal tersebut dapat ditemukan dalam Pasal 1915 KUHPerdata yang berbunyi: "Persangkaan-persangkaan ialah kesimpulankesimpulan yang oleh undang-undang atau oleh hakim ditariknya dari suatu peristiwa yang dikenal kearah suatu peristiwa yang tidak dikenal".

Berdasarkan Pasal 164 HIR dan 1866 KUHPerdata diatur dengan tegas bahwa persangkaan adalah alat pembuktian. Pada hakekatnya yang dimaksudkan dengan persangkaan tidak lain adalah alat bukti yang bersifat tidak langsung. ${ }^{10}$ Walaupun telah dijelaskan dalam undang-undang bahwa persangkaan itu merupakan alat pembuktian, para ahli hukum tidak puas dengan ketentuan tersebut, maka dikemukakanlah berbagai dalih untuk mengugugurkan ketentuan tersebut. Oleh karena persangkaan adalah kesimpulan belaka, maka dalam hal ini yang dipakai sebagai alat bukti sebetulnya bukan persangkaan itu, melainkan alat-alat bukti lain, yaitu misalnya kesaksian atau surat-surat dan pengakuan satu pihak, yang membuktikan bahwa suatu peristiwa adalah terang ternyata. ${ }^{11}$

Jenis-jenis alat bukti persangkaan dapat dibagi menjadi:

a. Persangkaan Berdasarkan Undang-undang

Yang dimaksud dengan persangkaan menurut undang-undang berdasarkan Pasal 1916 KUHPerdata yaitu persangkaan yang berdasarkan suatu ketentuan khusus undang-undang, dihubungkan dengan perbuatan-perbuatan

\footnotetext{
${ }^{10}$ R.Wirjono Prodjodikoro, op cit, hlm. 116.

${ }^{11} \mathrm{Ibid}$, hlm. 117.
}

tertantu atau peristiwa-peristiwa tertentu. Bahkan dalam pasal yang sama undang-undang memberikan contoh-contohnya sebagai berikut:

1) Perbuatan yang oleh undang-undang dinyatakan batal, karena semata-mata demi sifat dan wujudnya, dianggap telah dilakukan untuk menyelundupi suatu ketentuan undang-undang;

2) Hal-hal dimana oleh undang-undang diterangkan bahwa hak milik atau pembebasan utang disimpulkan dari keadaan-keadaan tertentu;

3) Kekuatan yang oleh undang-undang diberikan kepada suatu putusan hakim yang sudah memperoleh kekuatan hukum mutlak;

4) Kekuatan yang oleh undang-undang diberikan kepada pengakuan atau kepada sumpah salah satu pihak.

b. Persangkaan Yang Tidak Berdasarkan Undangundang

Tidak sebagaimana dalam persangkaan menurut undang-undang, hakim terikat pada ketentuan undang-undang akan tetapi dalam persangkaan yang tidak berdasarkan undang-undang, hakim bebas menyimpulkan persangkaan berdasarkan kenyataan. Hakim bebas mempergunakan atau tidak mempergunakan hal-hal yang terbukti dalam suatu perkara sebagai dasar untuk melakukan persangkaan. Persangkaan menurut kenyataan diatur dalam Pasal 173 HIR dan Pasal 1922 KUHPerdata yang berbunyi: "Persangkaanpersangkaan yang tidak berdasarkan undangundang sendiri, diserahkan kepada pertimbangan dan kewaspadaan hakim, yang namun itu tidak boleh memperhatikan persangkaan-persangkaan lain selainnya yang penting, teliti dan tertentu, dan sesuai satu sama lain. Persangkaan yang demikian hanyalah boleh dianggap dalam hal-hal dimana undang-undang mengizinkan pembuktian dengan saksi-saksi, begitu pula apabila dimajukan suatu bantahan terhadap suatu perbuatan atau suatu akta, berdasarkan alas an adanya itikad buruk atau penipuan"

\section{Bukti Pengakuan}

Bukti pengakuan baik HIR maupun KUHPerdata tidak menerangkan atau mengatur secara jelas. Bukti pengakuan dalam HIR diatur dalam Pasal 174 HIR, Pasal 175 HIR dan Pasal 176 HIR sedangkan dalam KUHPerdata diatur pada Pasal 1923 KUHPerdata sampai dengan Pasal 1928 KUHPerdata. Pengakuan 
adalah keterangan sepihak dari salah satu pihak dalam satu perkara, di mana ia mengakui apa yang dikemukakan oleh pihak lawan atau sebahagian dari apa yang dikemukakan oleh pihak lawan ${ }^{12}$.

Apabila berpedoman pada ketentuan undangundang maka mengenai pengakuan adalah jelas merupakan salah satu alat pembuktian, hal ini terbukti dengan memperhatikan ketentuan Pasal 164 HIR dan Pasal 1866 KUHPerdata. Walaupun undang-undang menganggap pengakuan itu sebagai salah satu alat pembuktian, akan tetapi banyak para ahli hukum yang berpendapat sebaliknya.

Hal-hal yang berhubungan dengan kekuatan pembuktian mengenai bukti pengakuan antara lain:

a. Pengakuan Yang Tidak Boleh Dipisah-Pisahkan Jika terdapat pengakuan dari salah satu pihak dalam persidangan berdasarkan Pasal 176 HIR dan Pasal 1924 KUH Perdata, memerintahkan kepada hakim untuk menerima pengakuan secara keseluruhan secara bulat dan tidak berwenang menerima pengakuan itu sebagian-sebagian, sehingga merugikan pihak yang mengemukakan pengakuan. Memisah-misahkan pengakuan itu hanya diizinkan apabila orang yang berhutang, dengan maksud untuk membebaskan dirinya, menyebutkan peristiwa-peristiwa yang terbukti tidak benar.

b. Pengakuan di Luar Sidang Pengadilan

Pengakuan di luar sidang pengadilan diatur dalam pasal 175 HIR, 1927 KUHPerdata dan 1928 KUH Perdata. Berdasarkan ketentuan hukum tersebut pengakuan diluar persidangan tidak dapat dipakai, selain dalam hal-hal yang diperkuat dengan bukti saksi-saksi. Mengenai hal ini seluruh bergantung sepenuhnya pada pertimbangan hakim untuk menentukan kekuatan mana yang akan diberikan kepada suatu pengakuan lisan yang dilakukan di luar sidang pengadilan.

\section{Bukti Sumpah}

Perihal mengenai bukti sumpah HIR maupun KUHPerdata tidak memberikan definisi yang jelas dan lengkap. Undang-undang hanya mengatur tentang sumpah pada Pasal 155 HIR sampai dengan Pasal 158 HIR, Pasal 177 HIR dan Pasal 1929 KUHPerdata sampai dengan Pasal 1945 KUHPerdata. Walaupun undang-undang tidak menjelaskan arti sumpah, para ahli hukum memberikan pengertian mengenai bukti sumpah. Sumpah adalah hal menguatkan suatu keterangan dengan berseru kepada Tuhan. ${ }^{13}$

Sumpah pada umumnya adalah suatu pernyataan yang khidmat yang diberikan atau diucapkan pada waktu memberi janji atau keterangan dengan mengingat atau sifat maha kuasa daripada Tuhan, dan percaya bahwa siapa yang memberi keterangan atau janji yang tidak benar akan dihukum oleh-Nya. ${ }^{14}$

Walaupun undang-undang tidak menjelaskan arti sumpah secara detail dan jelas akan tetapi berdasarkan undang-undang ada dua macam sumpah yaitu:

1) Sumpah yang diperintahkan oleh hakim diatur dalam Pasal 1940 KUHPerdata sampai dengan Pasal 1943 KUHPerdata. Berdasarkan ketentuan tersebut hakim dapat, karena jabatannya memerintahkan kepada salah satu pihak yang berperkara untuk menggantungkan pemutusan perkara pada penyumpahan itu. Hakim dapat melakukan hal demikian hanya dalam dua hal (a) Jika tuntutan maupun tangkisan tidak terbukti dengan sempurna; (b) Jika tuntutan maupun tangkisan itu tidak terbukti sama sekali. Dalam prakteknya hal ini sangat jarang terjadi bahkan hampir belum pernah terjadi, karena bukti sumpah menurut undang-undang ini adalah inisiatif dari hakim yang memeriksa perkara, dimana hakim harus aktif. Hal ini dinilai bertentangan dengan asas pemeriksaan perkara perdata dimana hakim bersikap pasif.

2) Sumpah yang dimohonkan oleh pihak lawan diatur dalam Pasal 1930 KUHPerdata sampai dengan Pasal 1939 KUH Perdata. Berdasarkan ketentuan tersebut permohonan untuk sumpah berasal dari para pihak yang bersengketa, akan tetapin tetap harus disampaikan kepada hakim yang memeriksa. Dalam Pasal 1930 KUHPerdata disebut dengan sumpah pemutus yang dapat diajukan oleh para pihak dalam setiap tingkatan perkara.

\footnotetext{
${ }^{12}$ A.Pitlo, 1978, Pembuktian dan Daluwarsa, Intermasa Jakarta, hlm. 150 .
}

\footnotetext{
${ }^{13}$ Ibid, hlm.172.

${ }^{14}$ Sudikno Mertokusumo, op cit, hlm. 147.
} 


\section{Kesimpulan}

1. Pembuktian adalah tindakan membuktikan secara umum memiliki tujuan yang sama yaitu guna memberikan kepastian tentang kebenaran suatu peristiwa. Tindakan membuktikan dalam suatu persidangan memang digunakan pengertian pembuktian secara yuridis yaitu pembuktian di persidangan tidak dimungkinkan adanya pembuktian yang logis dan mutlak, oleh karenanya dalam pemeriksaan bukti-bukti dipersidangan dikenal dengan istilah hal-hal yang mendekati kebenaran. Akan tetapi sebenarnya jika dianalisa lebih dalam lagi dalam hal-hal tertentu dapat juga terjadi pembuktian dipersidangan itu bersifat logis dan mutlak;

2. Perbedaan pembuktian dalam hukum acara pidana danhukumacaraperdataadalahdalampembuktian pidana sistem pembuktiannya negatief wettelijk stelsel yaitu sistem pembuktian menurut undangundang secara negatif merupakan teori gabungan antara sitem pembuktian menurut undangundang secara positif dengan sistem pembuktian menurut keyakinan atau conviction- in time. Sedangkan Karakteristik dalam pembuktian perdata adalah audi et alterem partem yaitu pihak yang mendalilkan harus membuktikan dalilnya tersebut; 


\section{DAFTAR PUSTAKA}

\section{Buku}

Dirdjosisworo,Soedjono, 1984, Filsafat Peradilan dan Perbandingan Hukum, Armico, Bandung.

Hamzah,Andi, 2008, Hukum Acara Pidana Indonesia, Edisi Kedua, Sinar Grafika, Jakarta.

, 2011, Delik-Delik Tertentu (Speciale Delicten) Di Dalam KUHP, Universitas Triksakti, Jakarta.

Harahap, M.Yahya, 2001, Pembahasan Permasalahan dan Penerapan KUHAP (Pemeriksaan Sidang Pengadilan, Banding, Kasasi, dan Peninjauan Kembali) Edisi Kedua, Sinar Grafika, Jakarta.

2001, Pembahasan Permasalahan Dan Penerapan KUHP (Penyidikan dan

Penuntutan) Edisi Kedua, Sinar Grafika, Jakarta.

, 2004, Hukum Acara Perdata tentang Gugatan Persidangan, Penyitaan, Pembuktian, dan

Putusan Pengadilan, Sinar Grafika, Jakarta.

Iswahyudi, Sudhono, 2000, Penanganan Tindak Pidana Korupsi di Indonesia, PT. Gramedia, Jakarta.

Mertokusumo, Sudikno, 1988, Hukum Acara Perdata Indonesia, Liberty, Yogyakarta.

Nawawi, Arief Barda, 2001, Perbandingan Hukum Pidana, PT. Rajagrafindo Persada, Jakarta.

Nur Basuki Minarto, "Pembuktian Gratifikasi dan Suap dalam Tindak Pidana Korupsi”, Yuridika, Majalah Fakultas Hukum, UNAIR. Vol 20, No. 2, Maret 2005.

Pitlo, A,1978, yang berjudul Pembuktian Dan Daluwarsa, Intermasa, Jakarta.

Prodjohamidjojo, Martiman, 2001, Penerapan Pembuktian Terbalik Dalam Delik Korupsi ( UU No. 31 Tahun 1999), Mandar Maju, Bandung.

Prodjodikoro, Wirjono, 1985, Hukum Acara Perdata di Indonesia, Sumur, Bandung.

Samudera, Teguh, 2004, Hukum Pembuktian dalam Acara Perdata, PT Alumni, Bandung.

Sapardjaja, Komariah Emong, 2002, Ajaran Sifat Melawan Hukum Materiel Hukum Pidana Indonesia, Alumni, Bandung.

Sianturi, S.R, 1983, Tindak Pidana Di KUHP Berikut Uraiannya, Alumni AHM-PTHM, Jakarta.

Soesilo R, 1996, Kitab Undang-Undang Hukum Pidana (KUHP) Serta Komentar-Komentarnya Lengkap Pasal Demi Pasal, Politeia, Bogor.

Sutantio, Retnowulan dan Iskandar Oeripkartawinata, 1997, Hukum Acara Perdata dalam Teori dan Praktek, Mandar Maju, Bandung. 
Tresna R, 1996, Het Herziene Inlandsch

Reglement Komentar HIR, PT. Pradnya

Paramita, Jakarta.

\section{Peraturan Perundang-undangan}

Kitab Undang-undang Hukum Perdata, Staatsblad 1847 No. 23.

Kitab Undang-undang Hukum Pidana, Staatsblad 1915 No. 732.

Undang-undang No. 8 Tahun 1981 tentang Kitab Undang-undang Hukum Acara Pidana. Lembaran Negara Republik Indonesia 1981 No. 76, Tambahan Lembaran Negara Republik Indonesia No. 3209 